\title{
Walnut extract (Juglans regia L.) and its component ellagic acid exhibit anti-inflammatory activity in human aorta endothelial cells and osteoblastic activity in the cell line KS483
}

\author{
Z. Papoutsi ${ }^{1}$, E. Kassi ${ }^{1}$, I. Chinou ${ }^{2}$, M. Halabalaki ${ }^{2}$, L. A. Skaltsounis ${ }^{2}$ and P. Moutsatsou ${ }^{1}$ * \\ ${ }^{1}$ Department of Biological Chemistry, Medical School, University of Athens, 75 Mikras Asias Street, Goudi 11527, Athens, Greece \\ ${ }^{2}$ Laboratory of Pharmacognosy, Department of Pharmacy University of Athens, Panepistimioupolis, GR 15771 Zografou, Athens, \\ Greece \\ (Received 14 February 2007 - Revised 2 August 2007 - Accepted 8 August 2007)
}

Epidemiological studies suggest that the incidence of CVD and postmenopausal osteoporosis is low in the Mediterranean area, where herbs and nuts, among others, play an important role in nutrition. In the present study, we sought a role of walnuts (Juglans regia L.) in endothelial and bonecell function. As the endothelial cell expression of adhesion molecules has been recognised as an early step in inflammation and atherogenesis, we examined the effect of walnut methanolic extract and ellagic acid, one of its major polyphenolic components (as shown by HPLC analysis), on the expression of vascular cell adhesion molecule (VCAM)-1 and intracellular adhesion molecule (ICAM)-1 in human aortic endothelial cells. After incubating the cells with TNF- $\alpha(1 \mathrm{ng} / \mathrm{ml})$ in the absence and in the presence of walnut extract $(10-200 \mu \mathrm{g} / \mathrm{ml})$ or ellagic acid $\left(10^{-7}-10^{-5} \mathrm{M}\right)$, the VCAM-1 and ICAM-1 expression was quantified by cell-ELISA. We further evaluated the effect of walnut extract $(10-50 \mu \mathrm{g} / \mathrm{ml})$, in comparison with ellagic acid $\left(10^{-9}-10^{-6} \mathrm{M}\right)$, on nodule formation in the osteoblastic cell line KS483. Walnut extract and ellagic acid decreased significantly the TNF- $\alpha$-induced endothelial expression of both VCAM-1 and ICAM-1 $(P<0.01 ; P<0.001)$. Both walnut extract (at $10-25 \mu \mathrm{g} / \mathrm{ml})$ and ellagic acid (at $\left.10^{-9}-10^{-8} \mathrm{M}\right)$ induced nodule formation in KS483 osteoblasts. The present results suggest that the walnut extract has a high anti-atherogenic potential and a remarkable osteoblastic activity, an effect mediated, at least in part, by its major component ellagic acid. Such findings implicate the beneficial effect of a walnut-enriched diet on cardioprotection and bone loss.

Walnuts: Ellagic acid: Endothelial cells: Osteoblasts

CVD as well as osteoporosis constitute major health problems in elderly individuals. There is a marked European geographical distribution of postmenopausal osteoporosis and CVD, with rates being lower in Southern European countries. Among other factors, the Mediterranean diet, rich in herbs and nuts, seems to be strongly associated with this low incidence of degenerative diseases ${ }^{1-4}$.

The data on the specific dietary constituents that are involved in the health effects of the Mediterranean diet include, among others, antioxidant polyphenols, monounsaturated and polyunsaturated lipids and phyto-oestrogens ${ }^{5,6}$. Walnuts (Juglans regia) are rich in substances such as ellagic acid, a known polyphenol, $\alpha$-tocopherol (vitamin E), fibre, essential fatty acids, flavonoids and phenolic acids ${ }^{7,8}$. The high content of PUFA (linoleic and linolenic acid) in walnuts has been suggested to reduce the risk of heart disease by decreasing total and LDL-cholesterol and increasing HDL-cholesterol. This favourable lipid profile of nuts has previously been proposed as the mechanism of walnuts' apparent anti-atherogenic effect in $\operatorname{man}^{9-11}$. On the other hand, vitamin $\mathrm{E}(\alpha$-tocopherol), a dietary antioxidant component of walnuts, appears to be the most effective in reducing the risk of CVD, exerting its effect through increasing the antioxidant defence system ${ }^{12}$. Of note, ellagic acid, a polyphenol, is a major component of walnuts and it has been proposed to exert anti-atherogenic, anti-carcinogenic and antioxidative properties ${ }^{13-15}$ (Fig. 1).

The inflammatory process plays an important role in the pathogenesis of atherosclerosis through the interaction of the endothelium with the immune cells. Numerous signalling cascades have been elucidated and, among other functions, the inflammatory cytokine-induced adhesion molecules by the endothelium play a critical role in the inflammatory process and immune response ${ }^{16}$. The adhesion molecules, namely vascular cell adhesion molecule (VCAM)-1 and intracellular cell adhesion molecule (ICAM)-1, activated by inflammatory cytokines such as TNF- $\alpha$, participate in the initiation of this interaction. To evaluate the cardioprotective effect of walnut, beyond its cholesterol-lowering ability, we examined the potential of methanolic extract derived from walnuts, J. regia, as well as its major component ellagic acid, to inhibit the expression of adhesion molecules (VCAM-1 and ICAM-1), measured by cellELISA in human aorta endothelial cells (HAEC).

Abbreviations: EGM, endothelial growth medium; FBS, fetal bovine serum; HAEC, human aorta endothelial cells; ICAM, intracellular cell adhesion molecule; MC, 4-methylcatechol; MTT, 3-(4,5-dimethylthiazol-2-yl)-2,5-diphenyltetrazolium bromide; VCAM, vascular cell adhesion molecule.

* Corresponding author: Dr P. Moutsatsou, fax +30 2107462682 , email pmoutsatsou@med.uoa.gr 


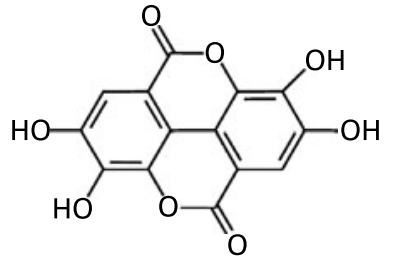

Fig. 1. Structure of ellagic acid.

Accumulating evidence points out that many of the pathophysiological events associated with CVD are also associated with low bone density ${ }^{17}$. In addition, recent data indicate that polyphenols, flavonoids and PUFA, major components in walnuts, exhibit favourable effects on bone health either by decreasing bone resorption or by increasing osteoblastic activity and bone formation ${ }^{18-24}$. In view of the above and because ellagic acid, a known polyphenol present in abundance in walnut methanolic extracts ${ }^{13,25-30}$, has shown a mineralisation effect on osteoblasts ${ }^{31}$, we assessed further the effect of walnut methanolic extract in osteoblasts and compared it with that observed in the presence of ellagic acid. We used an osteoblastic cell line (KS483) that has the ability to form mineralised nodules in vitro. The differentiation and mineralisation process, assessed by Alizarin Red-S staining, is a widely accepted assay that reflects the potential of tested compounds to promote osteoblastic activity.

\section{Experimental methods}

\section{Materials}

HAEC, as well as the endothelial cell basal medium and Single Quots Bulletin kit, containing human epidermal growth factor, hydrocortisone, gentamycin, amphotericin B, bovine brain extract and fetal bovine serum (FBS), were purchased from Clonetics ${ }^{\circledR}$ (Cambrex Corporation, East Rutherford, NJ, USA); all other cell-culture materials, such as $\alpha$-minimum essential medium, HEPES-buffered saline solution, trypsin-EDTA solution and Dulbecco's minimal essential medium and FBS were obtained from Invitrogen Life Technologies (Carlsbad, CA, USA). TNF- $\alpha$ (T0157), ( \pm )- $\alpha$-tocopherol (vitamin E; T3251), L-ascorbic acid (vitamin C; A4544), $\beta$-glycerophosphate (G9891), Alizarin Red-S (A5533), 17 $\beta$-oestradiol (E4389), 3-(4,5-dimethylthiazol-2-yl)-2,5-diphenyltetrazolium bromide (MTT; M5655) and the peroxidase substrate $o$-phenylendiamine hydrochloride (FAST ${ }^{\mathrm{TM}}$ OPD; P9187) were obtained from Sigma-Aldrich (St Louis, MO, USA). V-CAM antibody (M7106) was purchased from DakoCytomation (Glostrup, Denmark), I-CAM antibody (BBA3) was purchased from R\&D Systems (Minneapolis, MN, USA) and sheep anti-mouse IgG secondary antibody (NA931) was purchased from Amersham (Little Chalfont, Bucks, UK). All other chemical materials were purchased from Sigma-Aldrich, Fluka (Buchs, Switzerland) and BioRad (Hercules, CA, USA).

\section{Preparation of the extract and ellagic acid}

A quantity of $1260 \mathrm{~g}$ powdered peeled dried fruits of J. regia L. were extracted at room temperature, firstly to be defatted, with cyclohexane $(3 \times 2500 \mathrm{ml})$, giving $387 \mathrm{~g}$ of a yellow oily residue, after the evaporation of the solvent. Then, the plant material was extracted with methanol $(3 \times 2000 \mathrm{ml})$ and, after evaporation of the solvent, an orange oily extract $(412 \mathrm{~g}$ ) was obtained. A quantity of $4 \mathrm{~g}$ of the methanolic extract was subjected to reverse-phase column HPLC $(15 \times 230 \mathrm{~mm}$, Buchi, R18 silica gel 60, 20-40 mm; Merck, Darmstadt, Germany) and eluted with water followed by water-methanol mixtures $(250 \mathrm{ml}$ each one $)$ of decreasing polarity, to yield eight major fractions. Fraction 5 was further purified on Sephadex LH-20 CC eluted with methanol to provide ellagic acid $(25 \mathrm{mg})$. The chemical structure of ellagic acid was identified by direct comparison with an authentic sample (through TLC and NMR spectroscopy).

\section{High-performance liquid chromatography analysis}

Analytical HPLC was performed using the Thermo Finnigan HPLC system with a photodiode-array detector (Spectra System UV6000LP; Thermo Scientific, Waltham, MA, USA) and scanning wavelength range $200-380 \mathrm{~nm}$. Separations were carried out using a Lichrosorb RP 18 column $(250 \times 4.0 \mathrm{~mm}, 5.0 \mu \mathrm{m}$ particle size $)$ and the system was controlled by CromQuest ${ }^{\mathrm{TM}} 4.0$ software. The analysis was carried out with a binary mobile-phase gradient with a total flow rate of $1.0 \mathrm{ml} / \mathrm{min}$. Solvent A consisted of $2 \%$ acetic acid and solvent $\mathrm{B}$ consisted of $0.5 \%$ acetic acid-acetronitrile (ratio $1: 1$, $\mathrm{v} / \mathrm{v}$ ). The $80 \mathrm{~min}$ gradient method began with $90 \%$ A to $45 \%$ $\mathrm{A}$ in $50 \mathrm{~min}, 0 \% \mathrm{~A}$ in $10 \mathrm{~min}, 90 \% \mathrm{~A}$ in $5 \mathrm{~min}$ and finally $90 \%$ A for $15 \mathrm{~min}$ for equilibration between each analysis. The injection volume was $20 \mu \mathrm{l}$. Before analysis each sample was dissolved in $50 \%$ aqueous methanol to $10 \mathrm{mg} / \mathrm{ml}$ concentration for the methanolic extract and $1 \mathrm{mg} / \mathrm{ml}$ concentration for the pure compounds (standards) gallic acid, catechin, caffeic acid, coumaric acid and ellagic acid, which are some of the known predominant components in walnut phenolicenriched extracts. All the samples were passed through nylon acrodisc filters $(0.45 \mu \mathrm{m}$; Fisher Scientific, Pittsburgh, PA, USA) before analysis. The identification of the compounds contained in the extract was achieved through the comparison of their retention times and absorption maxima in the scanned spectrum with those of standard solutions.

\section{Determination of total polyphenol content}

Dry total methanolic extract $(267 \mathrm{mg}$ ) was extracted with $2 \mathrm{ml}$ methanol. After centrifugation for the removal of insoluble material the supernatant fraction was examined for polyphenol content using the Folin-Ciocalteau reagent ${ }^{13}$ using 4-methylcatechol (MC) as the standard for the preparation of the calibration curve.

\section{Culture of endothelial cells}

HAEC were cultured at $37^{\circ} \mathrm{C}$ in a humidified $95 \%$ air $-5 \%$ $\mathrm{CO}_{2}$ atmosphere in endothelial cell basal medium supplemented with human epidermal growth factor $(10 \mathrm{ng} / \mathrm{ml})$, hydrocortisone $(1 \mathrm{mg} / \mathrm{ml})$, gentamycin $(50 \mathrm{mg} / \mathrm{ml})$, amphotericin B $(50 \mathrm{ng} / \mathrm{ml})$, bovine brain extract $(12 \mu \mathrm{g} / \mathrm{ml})$ and FBS (2\%) (called hereafter endothelial growth medium (EGM)). At $70-80 \%$ confluence, cells were washed twice with 
HEPES-buffered saline solution ( $\mathrm{pH} 7 \cdot 2-7 \cdot 5)$, harvested with $0.025 \%$ trypsin-0.01\% EDTA and plated at a density $2500 \mathrm{cell} / \mathrm{cm}^{2}$. All experiments used HAEC of passage four to eight. For experiments, cells were grown to confluence in ninety-six-well plates using EGM. Cells were washed once with HEPES-buffered saline solution $(\mathrm{pH} \mathrm{7.2-7.5)}$ and then fresh EGM containing methanolic extract from $J$. regia at final concentrations of $10,50,200 \mu \mathrm{g} / \mathrm{ml}$ or ellagic acid at final concentrations of $10^{-7}-10^{-5} \mathrm{M}$ was added and an $18 \mathrm{~h}$ incubation period followed. Subsequently, TNF- $\alpha(1 \mathrm{ng} / \mathrm{ml})$ was added and the cells were incubated for an additional $6 \mathrm{~h}$ period. Cells treated with TNF- $\alpha(1 \mathrm{ng} / \mathrm{ml})$ alone and cells treated with $\mathrm{TNF}-\alpha(1 \mathrm{ng} / \mathrm{ml})$ plus $\alpha$-tocopherol $(20 \mu \mathrm{M})$ were also included. Control cells were incubated in EGM alone (without TNF- $\alpha$ or compounds). Subsequently, cells were used for the measurement of protein levels of cell adhesion molecules (VCAM-1 and ICAM-1) by cell-ELISA and for the assessment of cell viability by the MTT assay.

The preparation of $\alpha$-tocopherol solution was as follows: a stock solution of $\alpha$-tocopherol at $10 \mathrm{mg} / \mathrm{ml}$ was prepared in ethanol and stored at $-70^{\circ} \mathrm{C}$. To prepare $\alpha$-tocopherol solution for cell culture, stock solution was first mixed with FBS at a ratio of $1: 20$, then incubated at $37^{\circ} \mathrm{C}$ for $15 \mathrm{~min}$, during which time a brief vortex was conducted every 5 min. The FBS $-\alpha$-tocopherol solution was then diluted by EGM medium to make the final concentration of $\alpha$-tocopherol for supplementing $\mathrm{HAEC}^{12}$.

Measurement of cell adhesion molecules by cell-enzymelinked immunosorbent assay

Surface expression of VCAM-1 and ICAM-1 was quantified by cell-ELISA performed on an HAEC monolayer in flat-bottomed ninety-six-well plates as described previously ${ }^{32}$. Briefly, following incubation, the cells were fixed with $0.1 \%$ glutaraldehyde in PBS for $30 \mathrm{~min}$ at $4^{\circ} \mathrm{C}$. Plates were blocked at $37^{\circ} \mathrm{C}$ for $1 \mathrm{~h}$ with $5 \%$ skimmed milk powder in PBS, and an incubation at $4^{\circ} \mathrm{C}$ overnight with a primary monoclonal mouse antibody anti-human ICAM-1 or VCAM-1, at final concentration $2 \mu \mathrm{g} / \mathrm{ml}$ in $5 \%$ skimmed milk PBS, followed. Then the plates were washed three times with $0.1 \%$ Tween-20 in PBS and incubated with a horseradish peroxidase-conjugated sheep anti-mouse secondary antibody at a dilution of 1:5000 at room temperature for $1.5 \mathrm{~h}$. Subsequently, the plates were washed three times with $0.1 \%$ Tween-20 in PBS and finally the expression of cell adhesion molecules was quantified by the addition of the peroxidase substrate $o$-phenylendiamine hydrochloride. The absorption of each well was measured at $492 \mathrm{~nm}$ using a microplate spectrophotometer.

\section{Cell viability}

Cell viability was assessed by morphology under a phase-contrast microscope and by reduction of the tetrazolium salt MTT by mitochondrial dehydrogenases as described previously ${ }^{33}$. Briefly, after incubation of cells under all experimental conditions used, HAEC were washed twice with PBS and the medium was replaced with MTT dissolved at a final concentration of $1 \mathrm{mg} / \mathrm{ml}$ in Dulbecco's minimal essential medium (serum-free, phenol red-free) and a further $4 \mathrm{~h}$ incubation followed. Then, the MTT-formazan was solubilised in isopropanol and the optical density was measured at a wavelength of $550 \mathrm{~nm}$ and a reference wavelength of $690 \mathrm{~nm}$.

\section{Culture of KS483 osteoblastic cell line}

KS483 cells were grown in $\alpha$-minimum essential medium supplemented with $10 \% \mathrm{FBS}$ and penicillin-streptomycin, in a $\mathrm{CO}_{2}$ incubator $\left(5 \% \mathrm{CO}_{2}-95 \%\right.$ air $)$ at $37^{\circ} \mathrm{C}$ and subcultured every $3-4 \mathrm{~d}$ at a dilution $1: 5$ to $1: 6$ using a trypsin $0.125 \%$-EDTA $0.01 \%$ solution.

Before each experiment, cells were maintained for $3-4 \mathrm{~d}$ in $\alpha$-minimum essential medium (phenol red-free) supplemented with $10 \%$ dextran-coated charcoal-treated FBS. For the experiments, cells were seeded in twelve-well plates, at a density of $45000 /$ well and cultured in $\alpha$-minimum essential medium with $10 \%$ dextran-coated charcoal-treated FBS. At $3 \mathrm{~d}$ after plating, cells reached confluence and were subsequently induced to differentiate by the addition to the culture medium of ascorbic acid $(50 \mu \mathrm{g} / \mathrm{ml})$ and in the absence or presence of walnut methanolic extract at final concentrations of 10,25 and $50 \mu \mathrm{g} / \mathrm{ml}$. $17 \beta$-Oestradiol $\left(10^{-9}-10^{-6} \mathrm{M}\right)$ as well as ellagic acid $\left(10^{-9}-10^{-6} \mathrm{M}\right)$ were used as positive controls. $\beta$-Glycerophosphate was added after day 10 . The medium with the reagents was refreshed every $3-4 d$ for $24 d$ in total. After $24 \mathrm{~d}$, the cultures in twelve-well plates were rinsed with PBS, followed by fixation with $5 \%$ formalin for $10 \mathrm{~min}$ and stained for $\mathrm{Ca}$ deposition with Alizarin Red-S (solution $2 \%$; $\mathrm{pH} \mathrm{5.5)} \mathrm{for} 5 \mathrm{~min}$. Mineralised nodules were counted by light microscopy at a 10 -fold magnification as described previously.

\section{Statistical analysis}

Data are reported as mean values and standard deviations of three independent experiments (each experiment was conducted in triplicate or quadruplicate). Data in the figures are expressed as percentage of control, which was calculated as follows: (value for cells treated with compounds/value for control cells $) \times 100$. Statistical analysis was performed using Student's $t$ test, two-tailed distribution, assuming two-sample unequal variance.

\section{Results}

High-performance liquid chromatography and total polyphenol content

As shown in the chromatograph (Fig. 2), in the methanolic extract of walnut can be detected, among others, in considerable proportions the followings phenolic compounds: gallic acid, catechin, caffeic acid, coumaric acid and ellagic acid. Their retention times are 3.673, 9.983, 13.458, 21.275 and 33.292 min respectively.

The total polyphenol content in the dry methanolic extract was calculated to be 16.9 (SD 0.8) $\mu \mathrm{mol} \mathrm{MC} / \mathrm{g}$ dry substance.

Measurement of cell adhesion molecules by cell-enzymelinked immunosorbent assay

The effect of different concentrations of TNF- $\alpha$ ( 1 or $2 \mathrm{ng} / \mathrm{ml})$ on VCAM-1 and ICAM- 1 expression was initially determined 


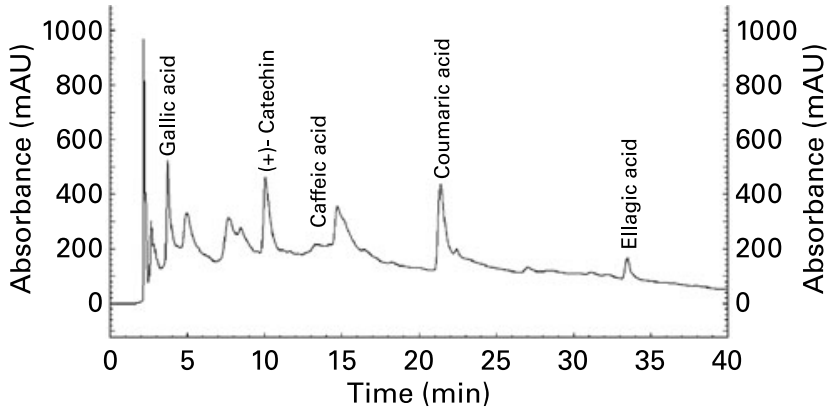

Fig. 2. HPLC chromatogram (Lichrosorb RP 18 column $(250 \times 4.0 \mathrm{~mm}$, $5.0 \mu \mathrm{m})$ at $280 \mathrm{~nm}$ ) of methanolic extract of walnuts (Juglans regia L.). mAU, milliabsorbance units.

after 6,12 or $24 \mathrm{~h}$ incubation. Incubation of confluent HAEC with TNF- $\alpha(1 \mathrm{ng} / \mathrm{ml})$ caused a maximal surface expression of VCAM-1 and ICAM-1 after $6 \mathrm{~h}$ of incubation (data not shown). In subsequent experiments, we used TNF- $\alpha$ $(1 \mathrm{ng} / \mathrm{ml})$ for $6 \mathrm{~h}$ to induce stimulation of cells. To investigate whether the plant extract derived from J. regia inhibits TNF$\alpha$-induced protein expression of adhesion molecules, confluent HAEC were treated for $18 \mathrm{~h}$ in the absence or presence of extracts at concentrations of $10-200 \mu \mathrm{g} / \mathrm{ml}$. Then, TNF- $\alpha$ $(1 \mathrm{ng} / \mathrm{ml})$ was added and cells were incubated for another $6 \mathrm{~h}$ period. Confluent HAEC incubated with $\alpha$-tocopherol $(20 \mu \mathrm{M})$ plus TNF- $\alpha(1 \mathrm{ng} / \mathrm{ml})$ served as the positive control, whereas cells without TNF- $\alpha$ and compounds comprised the control cells.

TNF- $\alpha$ increased the basal expression (control) of cell adhesion molecules VCAM-1 and ICAM-1 of confluent HAEC by 201.5 (SD 15.5) and 209.9 (SD 9.4) \% respectively. $\alpha$-Tocopherol decreased significantly the TNF- $\alpha$-induced endothelial expression of both V-CAM and I-CAM $(P<0.001)$, as expected. J. regia methanolic extract decreased TNF- $\alpha$-induced endothelial expression of both VCAM-1 (Fig. 3 (A)) and ICAM-1 (Fig. 3 (B)) at a concentration range of $10-200 \mu \mathrm{g} /$ $\mathrm{ml}$ in a statistically significant way $(P<0.01$ to $P<0.001)$. Ellagic acid decreased TNF- $\alpha$-induced endothelial expression of VCAM-1 and ICAM-1 at a concentration range of $10^{-7}-10^{-5} \mathrm{M}$ in a statistically significant way $(P<0.05$ to $P<0 \cdot 0010)$

\section{Cell viability}

The assessment of cell viability revealed that neither the morphology nor the reduction of MTT salt in HAEC was affected by any of the compounds (plant extracts, $\alpha$-tocopherol or $\mathrm{TNF}-\alpha$ ) at any concentration range or experimental conditions used. The lowering effect of the walnut extract and ellagic acid on the expression of adhesion molecules without affecting the proliferation rate of cells supports the anti-inflammatory activity of the compounds tested.

\section{Mineralisation effect on KS483 osteoblasts}

The bone study revealed that the methanolic extract of walnut induced nodule formation. Fig. 4 shows the effect of vehicle control (in the absence of compounds), 17 $\beta$-oestradiol and walnut extract on the mineralised nodule formation.
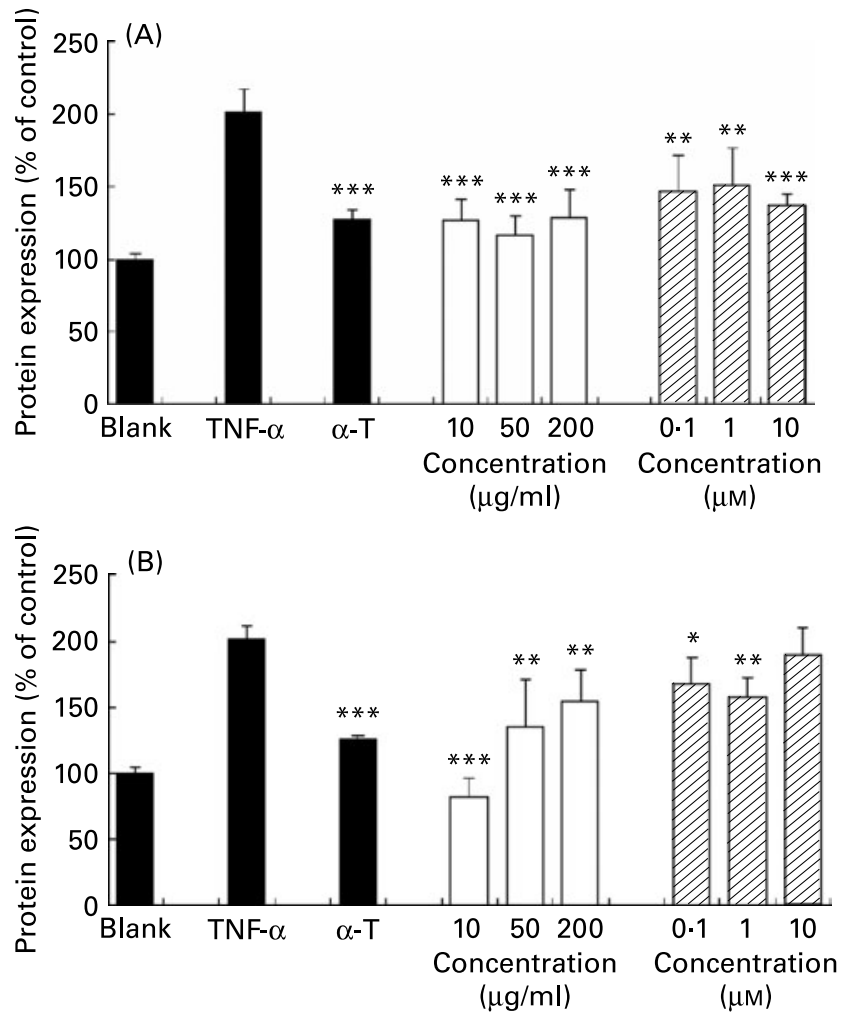

Fig. 3. Extracts inhibit TNF- $\alpha$-induced vascular cell adhesion molecule-1 (A) and intracellular cell adhesion molecule-1 (B) protein expression in human aorta endothelial cells (HAEC). As described in the Materials and methods section, HAEC were incubated in the absence of TNF- $\alpha$ or methanolic extract (control), with $\alpha$-tocopherol $(\alpha-\mathrm{T} ; 20 \mu \mathrm{M})$, or with different concentrations of walnut (Juglans regia L.) extract $(\square ; 10,50,200 \mu \mathrm{g} / \mathrm{ml}$ ) or ellagic acid $\left(\mathbb{2} ; 10^{-7}-10^{-5} \mathrm{M}\right)$ for $18 \mathrm{~h}$, followed by stimulation with TNF- $\alpha$ $(1 \mathrm{ng} / \mathrm{ml})$ for up to $24 \mathrm{~h}$. Adhesion molecules were measured by cell-ELISA. Data are expressed as percentage of control and shown as means of three independent experiments (each conducted in triplicate), with standard deviations represented by vertical bars. Mean value was significantly different from that of TNF- $\alpha$-treated cells: ${ }^{\star} P<0.05,{ }^{\star \star} P<0.01,{ }^{\star \star \star} P<0.001$.

$17 \beta$-Oestradiol at a concentration range of $10^{-7}-10^{-9} \mathrm{M}$ induced significantly the nodule formation, as expected. Ellagic acid at a low concentration range $\left(10^{-8}-10^{-9} \mathrm{M}\right)$ induced significantly nodule formation $(P<0 \cdot 01$ and $P<0.05$, respectively). Treatment with the methanolic extract of $J$. regia stimulated the formation of mineralised nodules at concentrations of 10 and $25 \mu \mathrm{g} / \mathrm{ml}$ in a statistically significant way $(P<0.05$ and $P<0.001$, respectively).

\section{Discussion}

The cardiovascular protective effect of a walnut diet has been related to antioxidant and hypocholesterolaemic effects as well as via modulation of endothelial function ${ }^{9,10,13,34}$. Data, however, on the anti-inflammatory effects of walnuts are sparse. Since the binding and recruitment of circulating monocytes to vascular endothelial cells are early steps in the development of inflammation and atherosclerosis, mediated through cell adhesion molecules that are expressed on the surface of endothelial cells, we evaluated the potential of the methanolic extract of $J$. regia, rich in polyphenolic compounds, to 


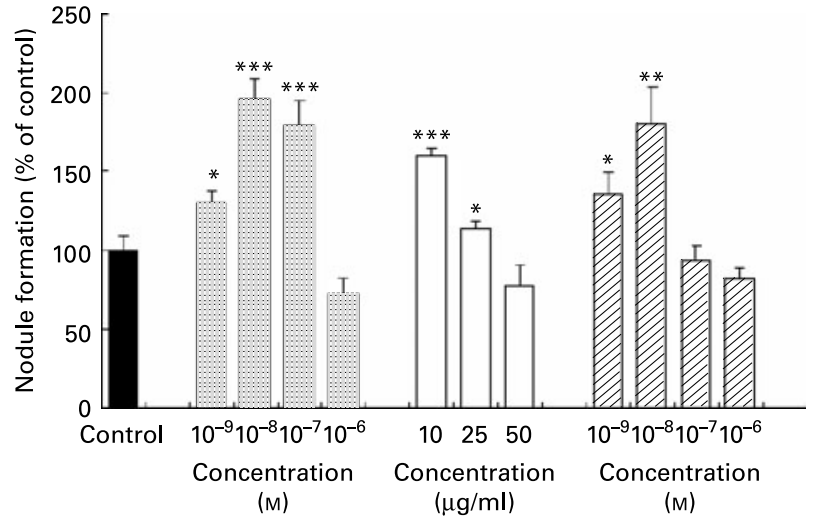

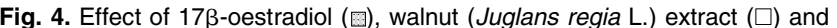
ellagic acid $(\mathbb{Z})$ on mineralisation of extracellular matrix in KS483 cells. Cells were exposed to vehicle control, $17 \beta$-oestradiol $\left(10^{-9}-10^{-6} \mathrm{M}\right)$, methanolic walnut extract $(10-50 \mu \mathrm{g} / \mathrm{ml})$ and ellagic acid $\left(10^{-9}-10^{-6} \mathrm{M}\right)$. Results are expressed as percentage of control (vehicle) and shown as means of the results of four cultures, with standard deviations represented by vertical bars. Mean value was significantly different from that of the vehicle control: ${ }^{\star} P<0.05,{ }^{\star *} P<0.01,{ }^{\star * *} P<0.001$

influence the expression of VCAM-1 and ICAM-1 by HAEC. We used the cell-ELISA to measure VCAM-1 and ICAM-1, a well-recognised in vitro assay to evaluate the anti-inflammatory effect of compounds or extracts ${ }^{35,36}$. As a positive control, we used vitamin E ( $\alpha$-tocopherol), an antioxidant known to exert its effect through modulation of cytokines, adhesion molecules, mobilisation of NF- $\mathrm{BB}$ transcription factor and interaction of immune cells with endothelial cells ${ }^{12,37}$. In the present study, the data from the walnut methanolic extract were compared with those from ellagic acid in view of its large contribution to the total polyphenolic content. Previous reports have also demonstrated the abundance of ellagic acid in walnut extract ${ }^{13,25-30}$. In order to decide the proper dosages of walnut methanolic extract and ellagic acid to be tested in our in vitro systems, we considered it important to take into account the following: (1) one serving of walnuts of $50 \mathrm{~g}$ corresponds to eight or nine shelled walnuts ${ }^{13}$; (2) experimental evidence supports that $50 \mu \mathrm{M}$-ellagic acid is equivalent to the dietary intake of approximately $200 \mathrm{~g}$ blackberries (about $90 \mathrm{mg}$ ellagic acid) or $350 \mathrm{~g}$ strawberries (about $70 \mathrm{mg}$ ellagic acid) ${ }^{15,38-41}$; (3) a bioavailability study has shown that consumption of a pomegranate juice $(180 \mathrm{ml})$ containing ellagic acid (25 mg) and ellagitannins (318 $\mathrm{mg}$ ) resulted (after $1-3 \mathrm{~h}$ post-injection) in ellagic acid plasma concentrations of 0.106 and $0.06 \mu \mathrm{M}$ respectively ${ }^{42}$; (4) our data on ellagic acid preparation indicate that $50 \mathrm{~g}$ of powdered peeled dried fruits of $J$. regia (eight or nine shelled walnuts) may result in approximately $100 \mathrm{mg}$ ellagic acid; (5) the polyphenol content of walnut methanolic extract determined in the present study was 16.9 (SD 0.8$) \mu \mathrm{mol} \mathrm{MC} / \mathrm{g}$ dry substance, implicating that the tested walnut extract concentrations $(10-200 \mu \mathrm{g} / \mathrm{ml})$ correspond to concentrations of approximately $0 \cdot 2-7.0 \mu \mathrm{mol} \mathrm{MC}$ equivalents which are within the range of expected physiological plasma levels of dietary phenolics ${ }^{43-47}$. Taken together, we decided to assess the biological effects of walnut extract at a concentration range of $10-200 \mu \mathrm{g} / \mathrm{ml}$ and ellagic acid at a concentration range of $10^{-9}-10^{-5} \mathrm{M}$, which are physiologically achievable and comparable concentrations. Previous studies have also shown that other polyphenolic compounds at similar concentrations, such as vitamin $\mathrm{E}(40 \mu \mathrm{M})$ or tea flavonoid $(60 \mu \mathrm{M}$-epigallocatechin-3-gallate), reduce cytokine-induced adhesion molecule expression and monocyte adhesion to endothelial cells ${ }^{48,49}$ Vitamin $\mathrm{E}$ inhibited the TNF- $\alpha$ induced expression of both ICAM-1 and VCAM-1, as expected ${ }^{12,50}$. The methanolic extract from walnuts inhibited the TNF- $\alpha$-induced endothelial activation and expression of ICAM- 1 and VCAM- 1 adhesion molecules, at a concentration range of $10-200 \mu \mathrm{g} / \mathrm{ml}$ or $0 \cdot 2-7 \mu \mathrm{mol} \mathrm{MC}$ equivalents which are within the reported in vitro concentration range of walnut extract shown to inhibit LDL oxidation ${ }^{13}$. The inhibitory effect of walnut extract was higher at low concentrations $(10 \mu \mathrm{g} / \mathrm{ml})$ than at higher concentrations $(200 \mu \mathrm{g} / \mathrm{ml})$, possibly due to the presence of multiple components present in the extract which may result in synergistic or antagonistic actions respectively ${ }^{51}$. Ellagic acid, a major component of walnut methanolic extract, inhibited also the TNF- $\alpha$-induced endothelial activation and expression of ICAM-1 and VCAM-1 adhesion molecules, when tested at a concentration range of $0 \cdot 1-10 \mu \mathrm{M}$. Yu et al. ${ }^{52}$ demonstrated that ellagic acid (at $25-50 \mu \mathrm{M}$ ) inhibited the IL-1 $\beta$-induced endothelial activation and expression of ICAM-1 and VCAM-1 adhesion molecules. Of note, they showed that ellagic acid mediated its anti-inflammatory effects via modulation of NF- $\kappa \mathrm{B}$ activity ${ }^{52}$. The present results and those reported by $\mathrm{Yu}$ et al. $^{52}$ imply that ellagic acid may confer the favourable effect of the walnut extract on endothelial function. However, this is not clearly confirmed by the present experiments since the walnut extract in the present study contained not only ellagic acid but other phenolic compounds such as gallic acid, catechin, caffeic acid and coumaric acid, which have been previously shown to inhibit endothelial activation and ICAM-1 and VCAM-1 expression ${ }^{49,53}$. Moreover, in vitro studies have demonstrated the ability of other compounds, also important constituents of walnuts, such as vitamins ( $\alpha$-tocopherol), other selected phenolics as well as PUFA, to inhibit endothelial activation and adhesion molecule expression $^{26,29,30,49,53-56}$. Thus, ellagic acid, despite being quantitatively a predominant polyphenol in walnut extract, may not be the primary determinant that predicts the antiinflammatory activity of walnut extract. Furthermore, it is important to mention that the ellagic acid present in walnut extract may be a result of its decomposition from ellagitannins, which are native molecules present in walnuts. Ellagitannins are polyphenols that occur as complex polymers of high molecular weight (up to $4000 \mathrm{kDa}$ ) and can be hydrolysed with acids or bases to yield ellagic acid, which can be used to indirectly quantify ellagitannins ${ }^{57}$.

Summarising, our data demonstrate the anti-inflammatory potential of polyphenolic-rich walnut extract and its abundant component ellagic acid on endothelial cells, at concentrations that are considered physiologically achievable in vivo. Such data provide a further insight into the mechanism of how walnut intake may participate in cardioprotection by improving endothelial function.

Bone remodelling is characterised by a balance between osteoclast bone resorption and osteoblast bone formation. Compounds that stimulate osteoblast proliferation, differentiation, mineralisation and survival, while are suppressors of osteoclastogenic molecules, are considered to favour bone function ${ }^{58,59}$. Since the control of osteoblast differentiation 
and mineralisation are among the key processes in the regulation of bone mass, we decided to assess the potential of walnut extract to induce mineralisation in osteoblasts. Previous work in our laboratory has shown that ellagic acid, similarly to oestradiol, exhibited significant osteoblastic activity in the KS483 cell line from mouse calvaria, which is a non-transformed stable subclone of a parental cell line KS483 that undergoes in vitro osteoblast differentiation in association with formation of a bone-like mineralised extracellular matrix, as evaluated by Alizarin Red-S staining ${ }^{31}$. Based on this reliable biological test, reflective of osteoblastic activity, we evaluated the potential of the methanolic extract of $J$. regia to stimulate mineralisation of osteoblasts in comparison with ellagic acid. We used as a positive control $17 \beta$-oestradiol $\left(10^{-9}-10^{-6} \mathrm{M}\right)$. Our findings revealed that the walnut extract stimulated the formation of mineralised nodules at a concentration range of $10-25 \mu \mathrm{g} / \mathrm{ml}$, which, of note, is within the reported range at which the extract is also efficacious in preventing adhesion molecule expression by the endothelial cells. Given the high contribution of ellagic acid to the total polyphenolic content in walnuts, it can be proposed that this phenolic compound may be considered, at least in part, as a potential contributor to the apparent favourable effect of the walnut extract on the mineralisation process in KS483 osteoblasts. However, previous investigators have reported that other compounds, also important constituents of walnuts such as flavonoids, other phenolics and n-3 PUFA, regulate various processes of bone function such as differentiation, apoptosis and bone resorption ${ }^{20-24}$. In addition, the combination of constituents present in walnut extract may result in synergistic or additive activity.

\section{Conclusions}

The methanolic extract from $J$. regia has a high anti-inflammatory potential that can be attributed, partly, to ellagic acid. Our data extend existing data regarding the cardioprotective effect of walnuts and provide a further molecular mechanism underlying the beneficial effect of walnuts on endothelial function. The beneficial effect of walnut extract and ellagic acid on osteoblast function suggests that the incorporation of walnuts into the diet may provide health benefits not only to the cardiovascular system, but also to the skeletal system by preventing osteoporosis.

\section{Acknowledgements}

We would like to thank Dr T. Yamashita, Head of Nephrology, Pharmaceutical Research Laboratories, Kirin Brewery Co., Ltd, Japan, and Dr M. Karperien, Department of Endocrinology and Metabolic Diseases, Leiden University Medical Center, The Netherlands, for providing us with the cell line KS483. We also thank the Bodossaki Foundation and the General Secretariat of Research and Technology, Ministry Development (EPET II) for financing the cell-culture facilities. The present study was supported by the grant EPAN TP27 from The General Secretariat of Research and Technology, Ministry of Development, in cooperation with the companies Gaea Products SA, Aktina SA, Yiotis SA, Pierre Fabre Hellas, and Attiki Bee Culturing Co. - Alexandros Pittas SA.

\section{References}

1. de Lorgeril M \& Salen P (2006) The Mediterranean-style diet for the prevention of cardiovascular diseases. Public Health Nutr 9, 118-123.

2. Kris-Etherton P, Eckel RH, Howard BV, St Jeor S \& Bazzarre TL (2001) AHA Science Advisory: Lyon Diet Heart Study. Benefits of a Mediterranean-style, National Cholesterol Education Program/American Heart Association Step I dietary pattern on cardiovascular disease. Circulation 103, 1823-1825.

3. Fogarty P, O'Beirne B \& Casey C (2005) Epidemiology of the most frequent diseases in the European a-symptomatic postmenopausal women. Is there any difference between Ireland and the rest of Europe? Maturitas 52, Suppl. 1, S3-S6.

4. Carluccio MA, Siculella L, Ancora MA, Massaro M, Scoditti E, Storelli C, Visioli F, Distante A \& De Caterina R (2003) Olive oil and red wine antioxidant polyphenols inhibit endothelial activation: antiatherogenic properties of Mediterranean diet phytochemicals. Arterioscler Thromb Vasc Biol 23, 622-629.

5. Gebauer SK, Psota TL, Harris WS \& Kris-Etherton PM (2006) $n-3$ Fatty acid dietary recommendations and food sources to achieve essentiality and cardiovascular benefits. Am J Clin Nutr 83, 1526S-1535S.

6. Kris-Etherton PM, Hecker KD, Bonanome A, Coval SM, Binkoski AE, Hilpert KF, Griel AE \& Etherton TD (2002) Bioactive compounds in foods: their role in the prevention of cardiovascular disease and cancer. Am J Med 113, Suppl. 9B, $71 \mathrm{~S}-88 \mathrm{~S}$

7. Maguire LS, O'Sullivan SM, Galvin K, O'Connor TP \& O'Brien NM (2004) Fatty acid profile, tocopherol, squalene and phytosterol content of walnuts, almonds, peanuts, hazelnuts and the macadamia nut. Int J Food Sci Nutr 55, 171-178.

8. Fukuda T, Ito H \& Yoshida T (2003) Antioxidative polyphenols from walnuts (Juglans regia L.). Phytochemistry 63, 795-801.

9. Almario RU, Vonghavaravat V, Wong R \& Kasim-Karakas SE (2001) Effects of walnut consumption on plasma fatty acids and lipoproteins in combined hyperlipidemia. Am J Clin Nutr 74, $72-79$.

10. Zambon D, Sabate J, Munoz S, Campero B, Casals E, Merlos M, Laguna JC \& Ros E (2000) Substituting walnuts for monounsaturated fat improves the serum lipid profile of hypercholesterolemic men and women. A randomized crossover trial. Ann Intern Med 132, 538-546.

11. Ros E, Nunez I, Perez-Heras A, Serra M, Gilabert R, Casals E \& Deulofeu R (2004) A walnut diet improves endothelial function in hypercholesterolemic subjects: a randomized crossover trial. Circulation 109, 1609-1614.

12. Wu D, Koga T, Martin KR \& Meydani M (1999) Effect of vitamin $\mathrm{E}$ on human aortic endothelial cell production of chemokines and adhesion to monocytes. Atherosclerosis 147, 297-307.

13. Anderson KJ, Teuber SS, Gobeille A, Cremin P, Waterhouse AL \& Steinberg FM (2001) Walnut polyphenolics inhibit in vitro human plasma and LDL oxidation. $J$ Nutr 131, $2837-2842$.

14. Festa F, Aglitti T, Duranti G, Ricordy R, Perticone P \& Cozzi R (2001) Strong antioxidant activity of ellagic acid in mammalian cells in vitro revealed by the comet assay. Anticancer Res 21, 3903-3908.

15. Mertens-Talcott SU, Talcott ST \& Percival SS (2003) Low concentrations of quercetin and ellagic acid synergistically influence proliferation, cytotoxicity and apoptosis in MOLT-4 human leukemia cells. J Nutr 133, 2669-2674.

16. Han SH, Quon MJ \& Koh KK (2007) Reciprocal relationships between abnormal metabolic parameters and endothelial dysfunction. Curr Opin Lipidol 18, 58-65. 
17. McFarlane SI, Muniyappa R, Shin JJ, Bahtiyar G \& Sowers JR (2004) Osteoporosis and cardiovascular disease: brittle bones and boned arteries, is there a link? Endocrine 23, 1-10.

18. Park YH, Han DW, Suh H, Ryu GH, Hyon SH, Cho BK \& Park JC (2003) Protective effects of green tea polyphenol against reactive oxygen species-induced oxidative stress in cultured rat calvarial osteoblast. Cell Biol Toxicol 19, 325-337.

19. Puel C, Quintin A, Mathey J, Obled C, Davicco MJ, Lebecque P, Kati-Coulibaly S, Horcajada MN \& Coxam V (2005) Prevention of bone loss by phloridzin, an apple polyphenol, in ovariectomized rats under inflammation conditions. Calcif Tissue Int 77, 311-318.

20. Griel AE, Kris-Etherton PM, Hilpert KF, Zhao G, West SG \& Corwin RL (2007) An increase in dietary $n$-3 fatty acids decreases a marker of bone resorption in humans. Nutr $J \mathbf{6}, 2$.

21. Hsu YL, Chang JK, Tsai CH, Chien TT \& Kuo PL (2007) Myricetin induces human osteoblast differentiation through bone morphogenetic protein-2/p38 mitogen-activated protein kinase pathway. Biochem Pharmacol 73, 504-514.

22. Kuo PL (2005) Myricetin inhibits the induction of anti-Fas IgM, tumor necrosis factor- $\alpha$ - and interleukin-1 $\beta$-mediated apoptosis by Fas pathway inhibition in human osteoblastic cell line MG-63. Life Sci 77, 2964-2976.

23. Bai XC, Lu D, Bai J, Zheng H, Ke ZY, Li XM \& Luo SQ (2004) Oxidative stress inhibits osteoblastic differentiation of bone cells by ERK and NF-кB. Biochem Biophys Res Comm 314, 197-207.

24. Tokuda H, Takai S, Hanai Y, Matsushima-Nishiwaki R, Hosoi T, Harada A, Ohta T \& Kozawa O (2007) (-)-Epigallocatechin gallate suppresses endothelin-1-induced interleukin- 6 synthesis in osteoblasts: inhibition of $\mathrm{p} 44 / \mathrm{p} 42$ MAP kinase activation. FEBS Lett 581, 1311-1316.

25. Colaric M, Veberic R, Solar A, Hudina M \& Stampar F (2005) Phenolic acids, syringaldehyde, and juglone in fruits of different cultivars of Juglans regia L. J Agric Food Chem 53, 6390-6396.

26. Li L, Tsao R, Yang R, Liu C, Zhu H \& Young JC (2006) Polyphenolic profiles and antioxidant activities of heartnut (Juglans ailanthifolia var cordiformis) and Persian walnut (Juglans regia L.). J Agric Food Chem 54, 8033-8040.

27. Jurd L (1956) Plant polyphenols. I. The polyphenolic constituents of the pellicle of the walnut (Juglans regia). J. Am Chem Soc 78, 3445-3448.

28. Jurd L (1958) Plant polyphenols. III. The isolation of a new ellagitannin from the pellicle of the walnut. Am Chem Soc 80, 2249-2252.

29. Stampar F, Solar A, Hudina M, Veberic R \& Colaric M (2006) Traditional walnut liqueur - cocktail of phenolics. Food Chem 95, 627-631

30. Jakopic J, Colaric M, Veberic R, Hudina M, Solar A \& Stampar F (2007) How much do cultivar and preparation time influence on phenolics content in walnut liqueur? Food Chem 104, 100-105.

31. Papoutsi Z, Kassi E, Tsiapara A, Fokialakis N, Chrousos GP \& Moutsatsou P (2005) Evaluation of estrogenic/antiestrogenic activity of ellagic acid via the estrogen receptor subtypes ER $\alpha$ and ER $\beta$. J Agric Food Chem 53, 7715-7720.

32. Zhang WJ, Stocker R, McCall MR, Forte TM \& Frei B (2002) Lack of inhibitory effect of HDL on TNF $\alpha$-induced adhesion molecule expression in human aortic endothelial cells. Atherosclerosis 165, 241-249.

33. Denizot F \& Lang R (1986) Rapid colorimetric assay for cell growth and survival. Modifications to the tetrazolium dye procedure giving improved sensitivity and reliability. J Immunol Methods 89, 271-277.

34. Tsuda K \& Nishio I (2004) Modulation of endothelial function by walnuts and sex hormones. Circulation 110, e73.
35. Kaneko M, Hayashi J, Saito I \& Miyasaka N (1996) Probucol downregulates E-selectin expression on cultured human vascular endothelial cells. Arterioscler Thromb Vasc Biol 16, $1047-1051$

36. Wolle J, Hill RR, Ferguson E, Devall LJ, Trivedi BK, Newton RS \& Saxena U (1996) Selective inhibition of tumor necrosis factor-induced vascular cell adhesion molecule-1 gene expression by a novel flavonoid. Lack of effect on transcription factor NF-кB. Arterioscler Thromb Vasc Biol 16, 1501-1508.

37. Weber C, Erl W, Pietsch A, Strobel M, Ziegler-Heitbrock HW \& Weber PC (1994) Antioxidants inhibit monocyte adhesion by suppressing nuclear factor- $\mathrm{kB}$ mobilization and induction of vascular cell adhesion molecule-1 in endothelial cells stimulated to generate radicals. Arterioscler Thromb 14, 1665-1673.

38. Walgren RA, Walle UK \& Walle T (1998) Transport of quercetin and its glucosides across human intestinal epithelial Caco-2 cells. Biochem Pharmacol 55, 1721-1727.

39. Whitley AC, Stoner GD, Darby MV \& Walle T (2003) Intestinal epithelial cell accumulation of the cancer preventive polyphenol ellagic acid - extensive binding to protein and DNA. Biochem Pharmacol 66, 907-915.

40. de Ancos B, Gonzalez EM \& Cano MP (2000) Ellagic acid, vitamin $\mathrm{C}$, and total phenolic contents and radical scavenging capacity affected by freezing and frozen storage in raspberry fruit. J Agric Food Chem 48, 4565-4570.

41. Sellappan S, Akoh CC \& Krewer G (2002) Phenolic compounds and antioxidant capacity of Georgia-grown blueberries and blackberries. J Agric Food Chem 50, 2432-2438.

42. Seeram NP, Lee R \& Heber D (2004) Bioavailability of ellagic acid in human plasma after consumption of ellagitannins from pomegranate (Punica granatum L.) juice. Clin Chim Acta $\mathbf{3 4 8 ,}$ $63-68$.

43. de Vries JH, Hollman PC, Meyboom S, Buysman MN, Zock PL, van Staveren WA \& Katan MB (1998) Plasma concentrations and urinary excretion of the antioxidant flavonols quercetin and kaempferol as biomarkers for dietary intake. Am J Clin Nutr 68, 60-65.

44. Wiseman H (1999) The bioavailability of non-nutrient plant factors: dietary flavonoids and phyto-oestrogens. Proc Nutr Soc 58, 139-146.

45. Manach C, Morand C, Crespy V, Demigne C, Texier O, Regerat F \& Remesy C (1998) Quercetin is recovered in human plasma as conjugated derivatives which retain antioxidant properties. FEBS Lett 426, 331-336.

46. Janssen K, Mensink RP, Cox FJ, Harryvan JL, Hovenier R, Hollman PC \& Katan MB (1998) Effects of the flavonoids quercetin and apigenin on hemostasis in healthy volunteers: results from an in vitro and a dietary supplement study. Am J Clin Nutr 67, 255-262.

47. Harris DM, Besselink E, Henning SM, Go VL \& Heber D (2005) Phytoestrogens induce differential estrogen receptor $\alpha$ or $\beta$-mediated responses in transfected breast cancer cells. Exp Biol Med (Maywood) 230, 558-568.

48. Islam KN, Devaraj S \& Jialal I (1998) $\alpha$-Tocopherol enrichment of monocytes decreases agonist-induced adhesion to human endothelial cells. Circulation 98, 2255-2261.

49. Ludwig A, Lorenz M, Grimbo N, Steinle F, Meiners S, Bartsch C, Stangl K, Baumann G \& Stangl V (2004) The tea flavonoid epigallocatechin-3-gallate reduces cytokine-induced VCAM-1 expression and monocyte adhesion to endothelial cells. Biochem Biophys Res Commun 316, 659-665.

50. Zapolska-Downar D, Zapolski-Downar A, Markiewski M, Ciechanowicz A, Kaczmarczyk M \& Naruszewicz M (2000) Selective inhibition by $\alpha$-tocopherol of vascular cell adhesion molecule-1 expression in human vascular endothelial cells. Biochem Biophys Res Commun 274, 609-615. 
51. Kassi E, Papoutsi Z, Fokialakis N, Messari I, Mitakou S \& Moutsatsou P (2004) Greek plant extracts exhibit selective estrogen receptor modulator (SERM)-like properties. J Agric Food Chem 52, 6956-6961.

52. Yu YM, Wang ZH, Liu CH \& Chen CS (2007) Ellagic acid inhibits IL-1 $\beta$-induced cell adhesion molecule expression in human umbilical vein endothelial cells. Br J Nutr 97, 692-698.

53. Murase T, Kume N, Hase T, Shibuya Y, Nishizawa Y, Tokimitsu I \& Kita T (1999) Gallates inhibit cytokine-induced nuclear translocation of NF- $\mathrm{B}$ and expression of leukocyte adhesion molecules in vascular endothelial cells. Arterioscler Thromb Vasc Biol 19, 1412-1420.

54. Kim JD, Liu L, Guo W \& Meydani M (2006) Chemical structure of flavonols in relation to modulation of angiogenesis and immune-endothelial cell adhesion. $J$ Nutr Biochem 17, $165-176$.

55. Lee G, Na HJ, Namkoong S, Jeong Kwon H, Han S, Ha KS, Kwon YG, Lee H \& Kim YM (2006) 4-O-methylgallic acid down-regulates endothelial adhesion molecule expression by inhibiting NF-кB-DNA-binding activity. Eur $J$ Pharmacol 551, $143-151$.

56. Zhao G, Etherton TD, Martin KR, West SG, Gillies PJ \& Kris-Etherton PM (2004) Dietary $\alpha$-linolenic acid reduces inflammatory and lipid cardiovascular risk factors in hypercholesterolemic men and women. J Nutr 134, 2991-2997.

57. Cerda B, Tomas-Barberan FA \& Espin JC (2005) Metabolism of antioxidant and chemopreventive ellagitannins from strawberries, raspberries, walnuts, and oak-aged wine in humans: identification of biomarkers and individual variability. J Agric Food Chem 53, 227-235.

58. Manolagas SC, Kousteni S \& Jilka RL (2002) Sex steroids and bone. Recent Prog Horm Res 57, 385-409.

59. Kousteni S, Han L, Chen JR, Almeida M, Plotkin LI, Bellido T \& Manolagas SC (2003) Kinase-mediated regulation of common transcription factors accounts for the bone-protective effects of sex steroids. J Clin Invest 111, 1651-1664. 